\title{
Biological Risk Assessment of Automobile Companies- A Case Study of Saipa as the Second Largest Iranian Car Manufacturer
}

\author{
SAMIRA SEIFALIAN ${ }^{1}$, HOSSEINYADEGARI ${ }^{2}$ and AKBAR MOKHTARI AZAR ${ }^{3 *}$ \\ 'Department of Bachelor of Environmental Health Engineering, University of Medicine, Qazvin, Iran. \\ ${ }^{2}$ Hospital Management Research Center, Iran University of Medical Sciences, Tehran, Iran. \\ ${ }^{3}$ Islamic Azad University, Tehran Medical Branch, Department of Health, Tehran, Iran.
}

http://dx.doi.org/10.12944/CWE.9.1.11

(Received: January 12, 2014; Accepted: March 02, 2014)

\begin{abstract}
In every careers and fields there are cases that known as risk and places that are categorized in biological risk centers that can be classified into specific classes. In HSE field also there are risk centers that can be indentified and validated separately and specifically. In definition; places and situation that are capable of existing or creating risk or can be a potential source of making risk are named risk centers. Risk centers in hygiene, immunity, and environment are different and have independent and separated identification. According to their extent of operating; these centers are less or more. In this investigation; tried to recording the huge part of biological risk centers in Saipa company. For this reason; a research plan was done for 12 months. That the first three months spent for searching on net and theorical investigation. Then, for nine months and with four experts biological risk centers were identify and related data was gathered and listed with software program Excel. The repeated cases were removed. After recognizing the biological risk centers, by operating method of number PJ-01-001 that is adoption of FMEA method, the risk were validated. In this evaluation every points were investigated and categorized into high, medium and low risk according to their occurrence, level of risk, frequency of occurrence, exposure to risk, control actions and ability of discovering risk. In the last four months, for the cases that categorized in high and medium risk fixing measures and actions were done. Related to unremitting and investigation; the cases that were in accordance with personnel, were noticed and a large number of these cases eliminated (about so percent) and the parts that needed. Instructions and appropriate actions were programmed and now are available for eliminate contradictions. Finally, it was determined since performing and noticing are not done and there is no training for it, it's not expectable that risk centers can be eliminated. According to this assessment, unremitting and continuing this process, in hygiene field, center of biological risk points were recognized and were diminished from 55 to 22 in less than four months. At last, considering the fact that the probability of occurring new risks are obvious; continuing the investigation and identification are recommended.
\end{abstract}

Key words: Inspection, The focus of biological risk, Health and safety, Risk assessment, Saipa CO, Corrective action.

\section{INTRODUCTION}

Human being has afallible nature whose mistakes are inevitable. Thereby, from ancient times people are looking for ways to reduce their risk of errors. In other words, by improving workplace conditions, well-designing the equipment, and adopting appropriate strategies, the risk-generating factors should be minimize as much as possible (Ahmadi 2005b). Prior to 1931, safety experts tend to focus on physical strategies such as machine guards, regardless of discipline and grooming considerations.

They believed that accidents are caused by inappropriate physical conditions. Preventive actions such as awareness programs by posters, brochures, training workshops, etc. could also be effective factor in mitigating risky activities. According to which, the individuals at risk will learn how to control incidences. Heinrich offered a total of ten items including theories and concepts of 
industrial safety rules (Lees Frank 2004 ; Whittingham 2004; Jahangiri 2004). Following Heinrich's thoughts, attentions have paid to the importance of unsafe activities as a main riskgenerating factor in industries (Ahmadi 2005a).

In 1960s, there was emphasized on preventive engineering on reduced technical defect and increased equipment reliability and safety barriers. After plane crashes in 1974, and 1980 as well as Three Miles Island in 1979, attention has drawn towards other issues of human fallibility, better education, improvement of human interactions - machinery, and support systems for the respond to the reduction and prevention of the spread of "human error" (Reason 2000; Ghalenoy 2006; Grozdanoviæ 2006).

Possibility index of human error is a quantitative and dynamic approach for taking into account human factors in risk assessment. This index is a method for identifying, evaluating and mitigating the risks associated with human errors during emergency conditions (DiMattia et al. 2005, Khan et al. 2006). Carlos Conte et al. (2011) presented a generalized utility model for the diagnosis and prediction of accidents among the Spanish work force with the aim of managing automatically work-related accidents at a national level. Jasch and Lavicka in 2006 was done a research on health and safety risk management of the Styrian automobile cluster in Austria. They prepared a management plan which is useful for small and medium sized companies as a starting point to shape their (EHS) system.

The present study aims at assessing biological risk center of Saipa Company as the second largest Iranian auto manufacturer.

\section{Method}

The present study lasted for 12 mounts in Saipa Company as the second largest automanufacturer in Iran. Accordingly, three environmental experts spent 6 mounts to detect biological risk centers in all parts of the company such as Production Unit including Painting Unit No. 1, Painting Unit No. 2, Body Unit No. 1, Body Unit No. 2, Assembly Unit No. 1, Assembly Unit No. 2, Press and non-production parts such as Power Post
Gas Central, Power House , fuel tanks , polymer, C.M.M ,chemistry, metallurgy and mechanic, chemical material, Etka, Shirazi land, Saipa3, Seico, Sale, Saipa5, office, clinic, triple salon, maintenance ,technical affairs, restaurant, public places, road test, treatment plant, waste, underground canals, and streets. The collected data were recorded, separately.

The famous PDCA Cycle suggested by Dr. Deming were used to detect and record risky processes. After identifying risky centers, appropriate strategies were presented to combat the risks.

Using Cocran formula, the number of visiting was calculated for each month in separation of different unities in the company.

According to available data and Cocaran formula, the number of visiting was 29 for each month. Using the Excel Software, a total of 29 - 46 places were selected to be visited in each month.

After detecting all risky centers during the study period of 6 months, some weekly meetings were held in which HSE (Health, Safety and Environment) managers, maintenance and repairs, technical and energy services managers were participated in order to find proper mitigation measures. Finally, a corrective action plan related to manufacturing and administrative units was prepared containing managerial strategies on

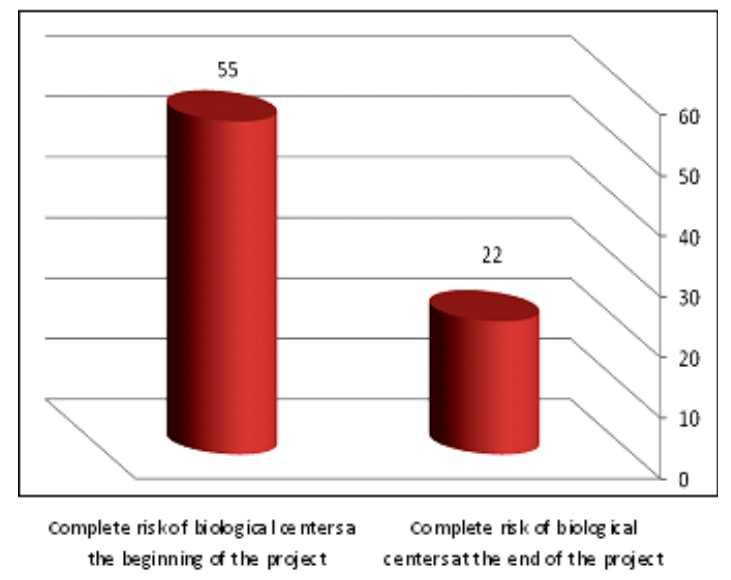

Fig.1:The reduction of biological risky centers in Saipa Company in duration of four month 
maintenance and repairs, as well as technical and energy services.

Corrective actions could be categorized in two types, one is related to equipments and another is associated with personnel behavior resolved by different ways (culture-building trainings, brochures, pamphlets, etc). Subsequently, Procedure number PJ-01-001 was used to evaluate risk levels of each risky centers based upon criteria occurrence probability, occurrence probability and intensity. This method includes those requirements recommended by the standard OHSAS 18001, 2007. Table 1 is a sample checklist of PJ-01-001 Procedure derived from FMEA Method by which risky factors are evaluated based on a three-point qualitative scale (high, medium and low).

For determination risk identified rate according to appendix form 1, at first compute intense and probability of occurrence risk from below table then determination risk rate according to evaluating matrix.

Table1: A sample checklist of PJ-01-001 Procedure to classify biological risky centers in Saipa Company

\begin{tabular}{|c|c|c|c|}
\hline Row & 2 & 6 & 7 \\
\hline place & Body 1 & Body 1 & Body 1 \\
\hline occupation & All personnel & All personnel & All personnel \\
\hline Stages of job & Eating and drinking & Daily works & Eating and drinking \\
\hline $\begin{array}{l}\text { Dangerous } \\
\text { (risky) }\end{array}$ & $\begin{array}{l}\text { Contamination with } \\
\text { disease }\end{array}$ & $\begin{array}{l}\text { Contamination } \\
\text { with disease }\end{array}$ & $\begin{array}{l}\text { Contamination } \\
\text { with disease }\end{array}$ \\
\hline Event & $\begin{array}{l}\text { Transmission disease } \\
\text { from hand during eating }\end{array}$ & $\begin{array}{l}\text { Transmission disease } \\
\text { from rats to personnel }\end{array}$ & $\begin{array}{l}\text { Transmission disease } \\
\text { from surfaces to personnel } \\
\text { and Gathering insects }\end{array}$ \\
\hline $\begin{array}{l}\text { Reason of } \\
\text { event }\end{array}$ & $\begin{array}{l}\text { Don't washing hands } d \\
\text { before eating foo }\end{array}$ & Existence Rats in hall & $\begin{array}{l}\text { Not cleaning tables and } \\
\text { teahouse }\end{array}$ \\
\hline Outcomes & Illness & IIIness & Illness \\
\hline $\begin{array}{l}\text { Control actions } \\
\text { of human }\end{array}$ & $\begin{array}{l}\text { Education Individual } \\
\text { health to all personnel }\end{array}$ & $\begin{array}{l}\text { Education Individual } \\
\text { health to all personnel }\end{array}$ & $\begin{array}{l}\text { Education Individual } \\
\text { health to all personnel }\end{array}$ \\
\hline Engineering & $\begin{array}{l}\text { Monthly visit and } \\
\text { declaration }\end{array}$ & $\begin{array}{l}\text { Monthly visit and } \\
\text { declaration }\end{array}$ & $\begin{array}{l}\text { Monthly visit and } \\
\text { declaration }\end{array}$ \\
\hline Control actions & $\begin{array}{l}\text { Non-compliances } \\
\text { to Contractors for solving } \\
\text { problem }\end{array}$ & $\begin{array}{l}\text { Non-compliances to } \\
\text { Contractors for solving } \\
\text { problem }\end{array}$ & $\begin{array}{l}\text { Non-compliances to } \\
\text { Contractors for solving } \\
\text { problem }\end{array}$ \\
\hline standard & has & has & has \\
\hline intense & 3 & 3 & 2 \\
\hline $\begin{array}{l}\text { Degree of } \\
\text { exposure }\end{array}$ & 8 & 8 & 8 \\
\hline $\begin{array}{l}\text { Frequency } \\
\text { outcome }\end{array}$ & 7 & 5 & 6 \\
\hline $\begin{array}{l}\text { Control } \\
\text { actions }\end{array}$ & 6 & 3 & 3 \\
\hline $\begin{array}{l}\text { Discover } \\
\text { Risk }\end{array}$ & 4 & 4 & 3 \\
\hline $\begin{array}{l}\text { Rate of } \\
\text { probability }\end{array}$ & 7 & 5 & 5 \\
\hline $\begin{array}{l}\text { The final } \\
\text { score }{ }^{*} P=R\end{array}$ & 21 & 15 & 10 \\
\hline Risk level & High & Medium & Low \\
\hline
\end{tabular}


In order to classify risky centers, the occurrence probability and intensity were initially be determined using Tables 2 and 3. Afterwards, they were ranked using the evaluating matrix.

Table 2: Intense rating determination

\begin{tabular}{ll}
\hline Rating & Human \\
\hline 7 & Death of more than 1 person \\
6 & Death of 1 person \\
5 & Disability over $60 \%$ \\
& Disability over $30 \%$ up to $60 \%$ \\
& Disability $10 \%$ up to $30 \%$ \\
3 & Disability less than $10 \%$ \\
2 & Medical break of 7 days up to 1 month \\
1 & Medical break of 2 days up to 7 \\
\hline
\end{tabular}

\section{Occurrence intensity}

The occurrence intensity was measured based on economic damages and losses to the personnel. Occurrence probability was determined as follows using the coefficients in Tables 3, 4 and 5.

1 Probability outcome (coefficient 6) (Table 3)

2 Degree of exposure (coefficient 8) (Table 3)

3 Human and engineering control actions (coefficient 10) (Table 4)

4 Ability to discover (coefficient 4) (Table 5)

The average of the mentioned coefficients was calculated using the following equation:

$\mathrm{P}$-(4*ability to discovery $+6^{*}$ outcome frequency $+8^{*}$ degree of exposure $+10^{*}$ control action)/28

Each of the factors was also calculated according to Tables 2,3 and 4. If the probability result

Table 3: Outcome frequency and exposure to risky factors

\begin{tabular}{|c|c|c|c|c|c|}
\hline \multicolumn{3}{|c|}{ Exposure to risk } & \multirow{2}{*}{$\begin{array}{l}\text { coeffi- } \\
\text { cient }\end{array}$} & \multirow[t]{2}{*}{ Outcome } & \multirow{2}{*}{$\begin{array}{l}\text { coefficient } \\
\text { frequency }\end{array}$} \\
\hline $\begin{array}{l}\text { General health } \\
\text { person/place }\end{array}$ & $\begin{array}{l}\text { Occupation } \\
\text { health }\end{array}$ & safety & & & \\
\hline $\begin{array}{l}\text { More than } \\
2000 \text { people }\end{array}$ & $>480$ & $\begin{array}{l}\text { Every day } \\
\text { exposure }\end{array}$ & 10 & $\begin{array}{l}\text { Every day } \\
\text { happening }\end{array}$ & 10 \\
\hline $1001-1999$ & $420-479$ & Every other day & 9 & One day among & 9 \\
\hline $501-1000$ & $360-419$ & Once a week & 8 & Once a week & 8 \\
\hline $301-500$ & $300-359$ & mid- week & 7 & mid-week & 7 \\
\hline $201-300$ & $240-299$ & Once a month & 6 & Once a month & 6 \\
\hline $101-200$ & $180-239$ & Every other 3 months & 5 & Every other 3 months & 5 \\
\hline $51-100$ & $120-179$ & Every other 6 months & 4 & Every other 6 months & 4 \\
\hline $11-50$ & $60-119$ & Once a year & 3 & Once a year & 3 \\
\hline $2-10$ & $30-59$ & Once in 5 years & 2 & Once in $1-5$ years & 2 \\
\hline 1 & $<29$ & $\begin{array}{l}\text { Once in more } \\
\text { than } 10 \text { years }\end{array}$ & 1 & $\begin{array}{l}\text { Once in more } \\
\text { than } 10 \text { years }\end{array}$ & 1 \\
\hline
\end{tabular}

Table 4: Rating for the scope of control actions required

\begin{tabular}{llll}
\hline Rate & Engineering & Rate & Human \\
\hline 8-10 & Lack of control action & 2 & Lack of awareness \\
$8-6$ & Low effectiveness of control action & 2 & Lack of personal protective equipment \\
$4-6$ & Medium effectiveness of control action & 2 & Lack of job satisfaction \\
$4-2$ & Good effectiveness of control action & 2 & Lack of job skills \\
$0-2$ & Full effectiveness of control action & 2 & Lack of health \\
10 & Rating & 10 & Overall rating \\
\hline
\end{tabular}


is a decisional number, the value will be roundedto one decimal place using the Equation 2.

$$
\begin{gathered}
X: \text { int erger and } y: \text { decimal }(X / y) \text { if } Y<5 \rightarrow x / y=[x] \\
\text { if } y=>5 \rightarrow x / y=[x]+1
\end{gathered}
$$

\section{RESULTS}

The studies showed that the biological risky centers detected during the six month of 2010 (September 23, 2010 to March 21, 2011) was 55 and in the next four months of 2011 correction action for all of the risky centers was issued. As a result, at the end of the fourth month the number of risky centers was reduced from 55 to 22 in the company;
$60 \%$ reduction in this less period in a large industrial company is a really good success.

Biological risky centers differ according to personnel function in production and administrative halls. A brief description is given in table 6 . However, it should be mentioned that some of these biological risky centers are common halls because as they have been detected in the WC (health services).

The result of evaluation on biological risky centers in production halls is shown in table 7 and tables 8 -13 shows the evaluation of biological risky centers in non-production parts of the company.

Table 5:Prioritization of risks

\begin{tabular}{lll}
\hline Example & Rating & Discovery \\
\hline The risk is easily recognized from a distance & $1-2$ & Quite obvious risk \\
Noise / light and ... Etc. has created & $4-3$ & It is understood by all five senses \\
Just seen or heard or ... & $6-5$ & Only one of the five senses can detect \\
The phase meter, thermometer conventional & $8-7$ & Should be used for the diagnosis of simple tools \\
Sensor or a digital tool & $9-10$ & Advanced tools are required to use \\
\hline
\end{tabular}

Table 6: The couple of examples of biological risky centers in company

\begin{tabular}{lll}
\hline $\begin{array}{l}\text { Others places and } \\
\text { common halls (place) }\end{array}$ & $\begin{array}{l}\text { Administrative } \\
\text { halls (place) }\end{array}$ & $\begin{array}{l}\text { Production } \\
\text { halls (place) }\end{array}$ \\
\hline $\begin{array}{ll}\text { The WC Being contaminated } \\
\text { (polluted or dirty) }\end{array}$ & $\begin{array}{l}\text { Desks surfaces and keyboards } \\
\text { being contaminated (polluted or dirty) } \\
\text { No trash door }\end{array}$ & $\begin{array}{l}\text { Small distance between } \\
\text { the personnel }\end{array}$ \\
$\begin{array}{ll}\text { Water tap damage in } & \text { Glasses being contaminated(dirty glasses) } \\
\text { WC (bathroom) } & \text { Oating food on the floor } \\
\end{array}$ & $\begin{array}{l}\text { and dirty cartons } \\
\text { protective devices(earmuff) }\end{array}$ \\
\hline
\end{tabular}

Table 7: The results of evaluation of biological risky centers in production halls

\begin{tabular}{llllll}
\hline & Place & Total & High & Medium & Low \\
\hline \multirow{2}{*}{ Production } & Body 1 & 33 & 2 & 13 & 18 \\
& Body 2 & 33 & 2 & 13 & 18 \\
& Press & 33 & 0 & 13 & 20 \\
& Dye tools & 33 & 0 & 10 & 23 \\
& paint 1 & 32 & 2 & 13 & 17 \\
& paint 2 & 33 & 0 & 14 & 19 \\
& Assembly 1 & 33 & 2 & 13 & 18 \\
& Assembly 2 & 34 & 2 & 18 & 14 \\
\hline
\end{tabular}


As you can see in table 7 amount of risk in high, medium and low are up to 2, 18 and 23 cases respectively in production halls.

As shown in table 8 , there is no high risk case in buildings and there are 2 and 32 cases for medium and low risk respectively

As shown in table 9, there is no high risk case in energy resources buildings and there are 3 cases with medium risk and for low risk cases there are 26 cases in power house and 2 cases in other places (Fuel tanks,gas central and power posts).

As shown in table 10, there is no high-risk case in laboratories but there are 2 and 11 cases in medium risk and low risk, respectively, just in C.M.M there is 2 cases with medium risk and 31 cases with low risk.

As shown in table 11, there is no high-risk case in storages but there are 7 and 28 cases with medium and low risk respectively

Out of company are places that do some of the business companies in abroad. As shown in Table 12, the subsidiary centers have no high-risk cases and there are 4 and 31 cases with medium and low risk respectively.

The variation of job (thing) in workshops usually is the same, for this reason the number of biological risky centers in all of them is the same 29 cases. As shown in Table 13, workshops (production halls) have no high-risk cases and there are 5 and 25 cases with medium and low risk respectively.

Table 8: The results of evaluation of biological risky centers in buildings

\begin{tabular}{rcccc}
\hline Place & Total & High & Medium & Low \\
\hline Buildings office & 34 & 0 & 2 & 32 \\
Clinic & 33 & 0 & 2 & 31 \\
\hline
\end{tabular}

Table 9:The results of evaluation of biological risky centers in energy resources buildings

\begin{tabular}{|c|c|c|c|c|c|c|}
\hline & & Place & Total & High & Medium & Low \\
\hline \multirow{4}{*}{\multicolumn{2}{|c|}{ Energy resources }} & Power post & 2 & 0 & 0 & 2 \\
\hline & & Gas central & 2 & 0 & 0 & 2 \\
\hline & & Powerhouse & 29 & 0 & 3 & 26 \\
\hline & & Fuel tanks & 2 & 0 & 0 & 2 \\
\hline \multicolumn{7}{|c|}{ Table 10: The results of evaluation of biological risky centers in laboratories } \\
\hline Place & Total & & High & Medium & Low & \\
\hline \multirow[t]{5}{*}{ Laboratories } & polyme & & 12 & 0 & 1 & 11 \\
\hline & C.M.M & & 33 & 0 & 2 & 31 \\
\hline & chemis & & 12 & 0 & 1 & 11 \\
\hline & power & & 12 & 0 & 1 & 11 \\
\hline & Metallu & gy \& mechanic & 12 & 0 & 1 & 11 \\
\hline \multicolumn{7}{|c|}{ Table 11: The results of evaluation of biological risky centers in storages } \\
\hline \multicolumn{3}{|c|}{ Place } & Total & High & Medium & Low \\
\hline \multirow[t]{4}{*}{ Warehouse } & \multicolumn{2}{|c|}{ Receipt of goods } & 30 & 0 & 2 & 28 \\
\hline & \multicolumn{2}{|c|}{ Chemical material } & 30 & 0 & 2 & 28 \\
\hline & \multicolumn{2}{|c|}{ Non-production } & 30 & 0 & 4 & 26 \\
\hline & \multicolumn{2}{|c|}{ Production } & 30 & 0 & 7 & 23 \\
\hline
\end{tabular}


Table 12: The results of evaluation of biological risky centers in out of company

\begin{tabular}{llcccc}
\hline & Place & Total & High & Medium & Low \\
\hline Out of & Etka & 27 & 0 & 4 & 23 \\
company & Shirazi land & 14 & 0 & 0 & 14 \\
& Saipa 3 & 33 & 0 & 2 & 31 \\
& Seico & 27 & 0 & 4 & 23 \\
& Sale & 33 & 0 & 2 & 31 \\
& Saipa 5 & 33 & 0 & 2 & 31 \\
\hline
\end{tabular}

Table 13: The results of evaluation of biological risky centers in workshops

\begin{tabular}{llcccc}
\hline & Place & Total & High & Medium & Low \\
\hline \multirow{2}{*}{ Workshops } & Technical affairs & 29 & 0 & 4 & 25 \\
& Triple salon & 29 & 0 & 5 & 24 \\
& Maintenance & 29 & 0 & 4 & 25 \\
\hline
\end{tabular}

Table 14: The results of evaluation of biological risky centers in site

\begin{tabular}{|c|c|c|c|c|c|}
\hline & Place & Total & High & Medium & Low \\
\hline \multirow[t]{8}{*}{ Site } & Restaurant & 41 & 2 & 32 & 7 \\
\hline & Public places & 20 & 0 & 6 & 14 \\
\hline & Road test & 14 & 0 & 1 & 13 \\
\hline & Treatment plant & 33 & 0 & 2 & 31 \\
\hline & Waste & 8 & 0 & 3 & 5 \\
\hline & Underground canals & 2 & 0 & 2 & 0 \\
\hline & Conex & 14 & 0 & 1 & 13 \\
\hline & streets & 10 & 1 & 6 & 3 \\
\hline
\end{tabular}

As shown in table 14, there are 2 cases with high risk in restaurant, 6 and 32 cases with medium risk in public places and restaurant respectively and 14 and 31 cases with low risk in public places and treatment plant respectively.

\section{CONCLUSION}

Today's world has undergone a variety of pollution of noise, water, soil, biological, etc. caused by human recklessness. Risk centers in hygiene, immunity, and environment are different and have independent and separated identification. According to their extent of operating; these centers are less or more. In this investigation; efforts were to record the huge part of biological risk centers in
Saipa company. For this reason; the present research was done to identify biological risk centers in SAIPA. After recognizing the biological risk centers using the method PJ-01-001, it was found that there are a total of 33 biological risks in the restaurant. Treatment plant (with a total of 33 risks), public places (with a total of 20 risks), and Road Test Unit (with a total of 14 risks) are the main risk generating centers in the company. Moreover, public places, Road Test Unit, Treatment Plant, Waste Disposal, underground canals, and Conex has no high-risk biological centers. Based upon the obtained results, it was revealed that mitigation measures should be focused on two places restaurant and treatment plant. 


\section{REFERENCES}

1. Ahmadi, A., Safety Management in Oil, Gas \& Petrochemical Industries. Vol.1: Engineering Approach to Human Errors. First Edition. Pourshad (2005a).

2. Ahmadi, A., Safety Management in Oil, Gas \& Petrochemical Industries. 2: (2005b) Preventing Methods from Occurring Human Errors in Oil related Industries .First Edition. Sepehr Fatemi

3. DiMattia, D.G., Khan, F.I. Amyotte, P.R.,Determination of human error probabilities for offshore platform musters, Journal of Loss Prevention in the Process Industries, 18: 488-501 (2005).

4. Ghalenoy, M., Safety Analysis for Control Room Operators Human Error in one of Petrochemical Industries using HEART Technique. MSC thesis. Tarbiat Modarres University (TMU) (2006).

5. Grozdanoviæ, M. and Stojiljkoviæ E., Framework for Human Error Quantification, Philosophy, Sociology and Psychology. 5: 18-23 (2006).
6. Jahangiri, M., Human Errors Identification And Analysis in Tehran Refinery Isomax Unit with PHEA technique. MSC thesis. Occupational Health Department, School of Public Health, Tehran University of Medical Science, (2004).

7. Khan, F.I., Amyotte, P.R. and DiMattia, D.G., HEPI: A new tool for human error probability calculation for offshore operation. Safety Science, 44: 313-334 (2006).

8. Lees Frank, P., Lees Loss Prevention in the Process Industries, 1: Third edition (2004).

9. Whittingham, R.B., The Blame Machine:Why Human Error Causes Accidents, Elsevier Butter worth-Heinemann (2004).

10. Carlos Conte J., Rubio E., Isabel García A., Cano F. Occupational accidents model based on risk-injury affinity groups. Safety Science, 49(2): 306-314 (2011).

11. Jasch Ch., Lavicka A. Pilot project on sustainability management accounting with the Styrian automobile cluster. Journal of Cleaner Production, 14(14), 1214-1227 (2006). 